\begin{tabular}{|c|c|c|}
\hline \hline & $\begin{array}{c}\text { International Journal of Current Research in } \\
\text { Biosciences and Plant Biology }\end{array}$ \\
\hline EXCELLENT \\
PUBLISHERS
\end{tabular}

\title{
Optimization of Monascus Pigment Production and its Antibacterial Activity
}

\author{
Neera*, Dhananjay Kumar, Karna Venkata Ramana and Rakesh Kumar Sharma
}

Food Biotechnology Division, Defence Food Research Laboratory, Defence Research and Development Organization, Siddarthanagar, Mysore-570 011, India

*Corresponding author.

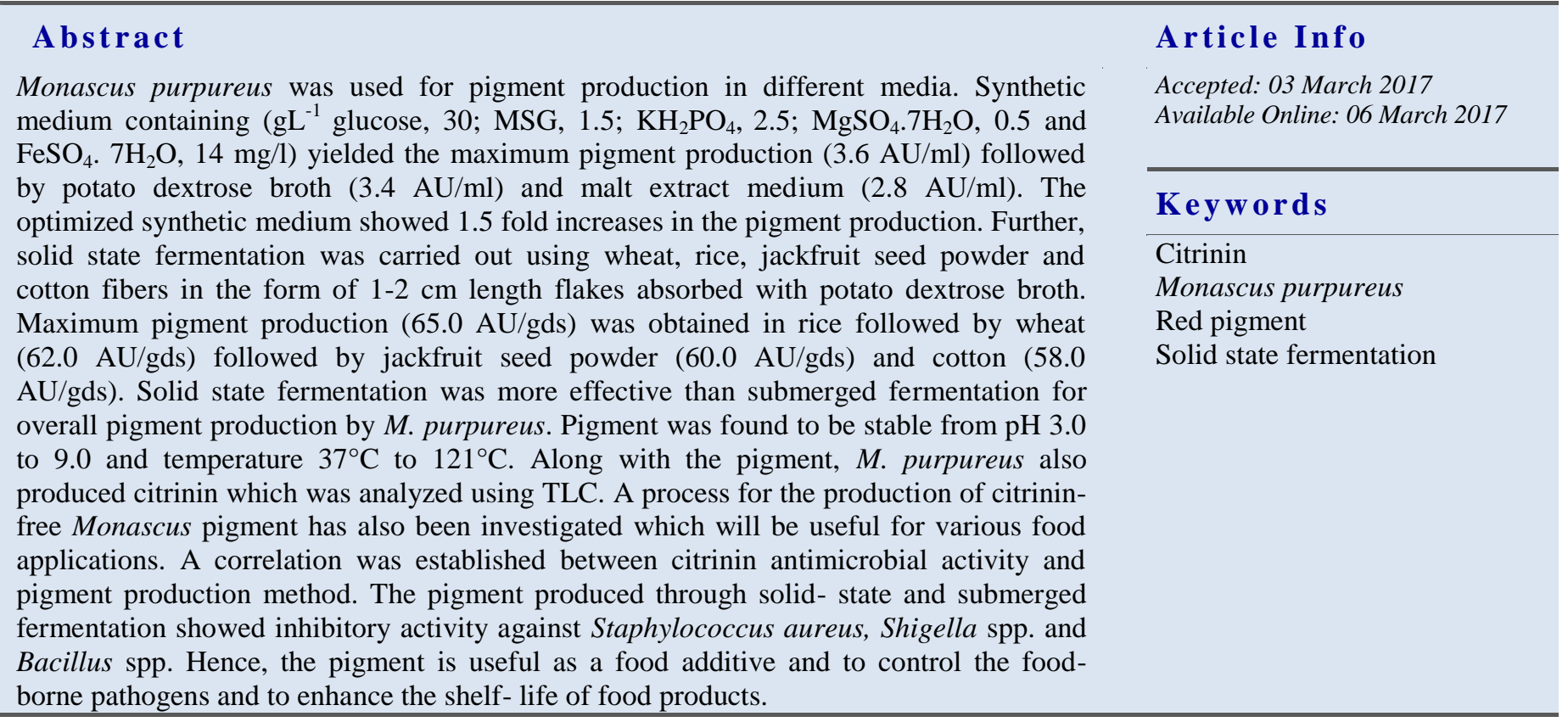

\section{Introduction}

In food processing industry, the attractive colorants are usually used to increase the food consumption (Babitha et al., 2006). But with increasing health and environment concerns, colours from natural sources are preferred over synthetic colours. Natural pigments and colorants are extracted from plants, animals, and microorganisms. Microbial pigments have an advantage over other sources as it can be produced rapidly under controlled physico- chemical conditions (Carvalho et al., 2007). Many microorganisms have the ability to produce pigments, including species of the genera Monascus, Cordyceps, Streptomyces, Phattia, Torula and Penicillium (Gunasekaran and Poorniammal, 2008).

Monascus pigments are used as food colorants and flavouring agents (Hajjaj et al., 2003). Monascus is able to produce strong red pigment including some useful 
primary metabolites such as ethyl alcohol, acids, esters, and other flavouring compounds and secondary metabolites i.e. pigments, lovastatin (monacolin), and antimicrobial agents (Hsu et al., 2010; Kono and Himeno, 1999). In addition, Monascus pigmented food is known to improve digestion as well as cardiovascular health. Monacolins (Monacolin K) inhibits the enzyme 3- hydroxyl-3- methylglutaryl- CoA reductase (HMGCoA reductase), key enzyme in cholesterol biosynthesis. Lovastatin, produced by some Monascus strains are known to lower blood cholesterol. In China, cholestin is a dietary supplement to promote normal cholesterol levels. Pigment production varies with cultivation conditions. These filamentous fungi or the pigments derived from them are mostly used as food colour in imitation crabmeat, soybean products, jellies, milk, ice cream, fish ketchup, rice wine, soyabean cheese and anka production (Hamano and Kilikian, 2006).

Monascus sp. are known to produce six types of pigments such as rubropunctatin (red colour), monascin (yellow colour), monascorubrin (red colour), ankaflavin (yellow colour), rubropunctamine (purple colour) and monascorubramine (purple colour), through polyketide pathway (Chang et al., 2002). Monascorubrin and rubropunctatin have high-affinity for compounds with primary amino groups (so-called aminophiles). These pigments react with amino acids to yield water-soluble red pigments, monascorubramine and rubropunctamine which are of more importance due to their red colour (Gunjan and Sanjay, 2011). Monascus pigments are safe as well as preferable due to their high affinity towards proteins, thermal stability and stability over a wide range of $\mathrm{pH}$ (Zhou et al., 2008). Some Monascus strains produce the antibiotic substance Monascidin A that has antimicrobial activity against Bacillus, Streptococcus, and Pseudomonas (Wong et al., 1981).

The Monascus red pigment production by submerged fermentation as well as solid-state fermentation is widely studied (Hajjaj et al., 2000a; Carvalho et al., 2005). Monascus pigmented rice also known as angkak or red mould rice is known for its beneficial effects for several centuries (Hesseltine, 1965). In spite of all these merits, Monascus is known to produce mycotoxin citrinin along with the pigment and other metabolites. The production of citrinin thus limits the use of Monascus as a producer of natural food colourants. Several filamentous fungi belonging to the genera Penicillium, Aspergillus and Monascus produces this toxic metabolite citrinin. The toxin is nephrotoxic and affects animals and humans. Although these pigments and citrinin are derived from the same tetraketide, but the enzymes involved in their synthesis have independent regulatory mechanisms of their genes (Pisareva et al., 2005).

The study was carried out for development of a bioprocess for enhanced production of red pigment using submerged and solid- state fermentation technology by Monascus purpureus in addition to producing citrinin- free pigment, using cotton flakes drenched with potato dextrose broth for food processing applications.

\section{Materials and methods}

\section{Culture}

Monascus purpureus MTCC 1090 strain was obtained from the Microbial Type Culture collection, Chandigarh, India. This organism was maintained on Potato Dextrose Agar (PDA) slants, subcultured and preserved at $4^{\circ} \mathrm{C}$ for further use.

\section{Inoculum preparation}

Monascus purpureus was streaked on PDA slants and incubated at $25^{\circ} \mathrm{C}$ for 5 days. A spore suspension was prepared by pouring $5 \mathrm{ml}$ of $0.1 \% \mathrm{v} / \mathrm{v}$ Tween 20 in distilled water directly over the slants. The spores were scrapped under aseptic condition and the spore suspension obtained was stored at $4{ }^{\circ} \mathrm{C}$ to be used for further inoculation. The spore suspensions were standardized to $1 \times 10^{6}$ spores/ $\mathrm{ml}$ by addition of $0.1 \%$ v/v Tween 20 in distilled water (Babitha et al., 2007).

\section{Monascus pigment production in submerged fermentation}

Submerged fermentation for pigment production was carried out in potato dextrose medium $\left(\mathrm{gL}^{-1}\right.$ potato infusion, 200; dextrose, 20), malt extract medium ( $\mathrm{gL}^{-1}$ malt extract, 17; peptone, 3) and synthetic medium (composition $\mathrm{gL}^{-1}$ glucose, 30; $\mathrm{MSG}, 1.5 ; \mathrm{KH}_{2} \mathrm{PO}_{4}$, 2.5; $\mathrm{MgSO}_{4} .7 \mathrm{H}_{2} \mathrm{O}, 0.5$ and $\left.\mathrm{FeSO}_{4} .7 \mathrm{H}_{2} \mathrm{O}, 14 \mathrm{mg} / \mathrm{l}\right)$. Hundred $\mathrm{ml}$ of each medium was added in $250 \mathrm{ml}$ flask and $\mathrm{pH}$ was adjusted to 5.5 with $1 \mathrm{~N} \mathrm{HCl}$ or $1 \mathrm{~N} \mathrm{NaOH}$. The media was autoclaved at $121^{\circ} \mathrm{C}$ for $15 \mathrm{~min}$. After cooling, these media were inoculated with $10 \%$ of spore suspension of $M$. purpureus culture and incubated at 
$25^{\circ} \mathrm{C}$ for 7 days at $150 \mathrm{rpm}$. Biomass and pigment production were assayed on $7^{\text {th }}$ day. Based on the pigment production data, synthetic medium was selected for further optimization.

\section{Effect of various carbon sources on biomass and pigment production}

In synthetic medium, glucose was substituted with various others carbon sources such as fructose, sucrose, maltose and lactose. The media was autoclaved at $121^{\circ} \mathrm{C}$ for $15 \mathrm{~min}$. The synthetic medium $(100 \mathrm{ml})$ in $250 \mathrm{ml}$ of flask was inoculated with $10 \%$ spore suspension of Monascus purpureus and was incubated at $25^{\circ} \mathrm{C}$ for 7 days at $150 \mathrm{rpm}$. For the analysis of yellow, orange and red pigments of the total product absorbance was measured at $400 \mathrm{~nm}, 470 \mathrm{~nm}$, and $510 \mathrm{~nm}$, respectively. Biomass content in different carbon sources were also estimated and reported in $\mathrm{g} / \mathrm{L}$.

\section{Effects of various nitrogen sources on biomass and pigment production}

In synthetic medium, MSG was substituted with various other nitrogen sources like peptone, yeast extract, ammonium nitrate and glutamic acid. The media was autoclaved at $121^{\circ} \mathrm{C}$ for $15 \mathrm{~min}$. Hundred $\mathrm{ml}$ of synthetic medium in $250 \mathrm{ml}$ of flask was inoculated with $10 \%$ spore suspension of Monascus purpureus, incubated for 7 days under shaking condition $150 \mathrm{rpm}$. For analysis of yellow, orange and red pigment absorbance was measured at $400 \mathrm{~nm}, 470 \mathrm{~nm}$, and $510 \mathrm{~nm}$ respectively. Biomass content in different carbon sources were also estimated and reported in $\mathrm{g} / \mathrm{L}$.

\section{Effect of $\mathrm{pH}$ on mycelium growth and pigment production}

The effect of initial medium $\mathrm{pH}$ was investigated to study its effect on mycelium growth and pigment production and $\mathrm{pH}$ of the optimized synthetic medium was adjusted to 3.0, 4.0, 5.0, 6.0, 7.0, 8.0 and 9.0 of 100 $\mathrm{ml}$ medium in $250 \mathrm{ml}$ of flask. The media was autoclaved at $121^{\circ} \mathrm{C}$ for $15 \mathrm{~min}$. It was further inoculated with $10 \%$ spore suspension of Monascus purpureus and incubation was carried out at $25^{\circ} \mathrm{C}$ for 7 days at $150 \mathrm{rpm}$. Pigment production was measured by taking Optical Density at 510nm using UV/ Vis spectrophotometer. For biomass estimation, mycelia separated from the broth by filtration (Whattman No. 1) was washed with distilled water and was weighed through pre-weighed membrane filters, after drying in an oven at $50^{\circ} \mathrm{C}$ for $24 \mathrm{hrs}$. The results were expressed in grams per liter. Final $\mathrm{pH}$ of media was also measured after 7 days of incubation.

\section{Effect of temperature on mycelium growth and pigment production}

The effect of temperature on mycelial growth and pigment production was studied by inoculating $100 \mathrm{ml}$ optimized synthetic medium with $10 \%$ spore suspension of $M$. purpureus and incubated at different temperature viz. $4^{\circ} \mathrm{C}, 15^{\circ} \mathrm{C}, 25^{\circ} \mathrm{C}, 37^{\circ} \mathrm{C}$ and $50^{\circ} \mathrm{C}$ for 7 days at 150 rpm. For biomass estimation, mycelia was separated from the broth by filtration (Whattman No. 1) and washed with distilled water and was weighed through pre-weighed membrane filters, after drying in an oven at $50^{\circ} \mathrm{C}$ for $24 \mathrm{hrs}$. The results were expressed in grams per litre.

\section{Monascus pigment production in solid- state fermentation}

For solid-state fermentation four substrates was chosen viz. local unpolished rice, wheat jackfruit seed powder and cotton. These were purchased from a local market of Mysore, India, and were used as substrate for pigment production by means of solid-state fermentation. Effect of solid substrate on pigment production has been investigated on Monascus purpureus after 10 days of incubation at $25^{\circ} \mathrm{C}$.

\section{Rice / Wheat substrate}

Initially, 50gm of rice/ wheat was soaked overnight in $150 \mathrm{ml}$ tap water. Water was drained off from rice/ wheat and it was spread over paper so as to drain extra water, and then crushed with mortar and pestle. Rice/wheat was supplemented with $0.5 \% \mathrm{MSG}$ and autoclaved at $121^{\circ} \mathrm{C}$ for 20 minutes and cooled. The substrate- based medium was inoculated with $10 \%$ seed culture of Monascus purpureus and kept at $25^{\circ} \mathrm{C}$ for 10 days. Moisture content was maintained up to $56-60 \%$ and calculated based on the basis of following formula:

\section{Moisture content of substrate $(\%)=$ $100 \times($ wet weight - dry weight $) /$ wet weight}

\section{Jackfruit seed powder}

Jackfruit seeds were obtained from a local market in 
Mysore as a waste material after consumption of the edible aril. The seed coats were removed and cotyledons sliced into thin chips, dried at $60^{\circ} \mathrm{C}$ for 12 hrs and then ground. Five grams of seed powder was taken into $250 \mathrm{ml}$ Erlenmeyer flask and salt solution (2 ml) containing (in $\mathrm{g} / \mathrm{L}$ ): $\mathrm{KH}_{2} \mathrm{PO}_{4} 2, \mathrm{NH}_{4} \mathrm{NO}_{3} 5, \mathrm{NaCl} 1$, and $\mathrm{MgSO}_{4} \cdot 7 \mathrm{H}_{2} \mathrm{O} 1$ was added. Initial moisture was set at $65 \%$ by adding the requisite amount of distilled water and mixed thoroughly, autoclaved at $121{ }^{\circ} \mathrm{C}$ for 15 minutes and cooled. It was inoculated with the $10 \%$ of seed culture of Monascus purpureus and incubated at $25^{\circ} \mathrm{C}$ for 10 days.

\section{Cotton}

Cotton (absorbent) was purchased from local market (usually used in microbiological laboratory for plugging conical flask for autoclaving) made into flakes $(1-2 \mathrm{~cm}$ long) and kept in roux flask. Potato dextrose broth (2X) containing $0.2 \%$ yeast extract was added to set the moisture level at 50\%. The flask was then autoclaved at $121{ }^{\circ} \mathrm{C}$ for $15 \mathrm{~min}$ and cooled. It was inoculated with $5 \%$ of seed culture of Monascus purpureus and incubated at $25^{\circ} \mathrm{C}$ for 10 days. Basic composition of agricultural products is given in Table 1 .

Table 1. Basic composition of agricultural products.

\begin{tabular}{llll}
\hline Agricultural product & Protein (\% w/w) & Carbohydrate (\% w/w) & Lipid (\% w/w) \\
\hline Wheat & 11.8 & 71.20 & 1.5 \\
Rice & 7.2 & 78.0 & 2.0 \\
Jackfruit seed powder & 11.2 & 51.82 & 0.99 \\
Cotton & 1.1 & 88.0 & 0.5 \\
\hline
\end{tabular}

\section{Pigment extraction}

Monascus pigments were extracted from different substrates using $95 \%$ ethanol at the rate of $5 \mathrm{ml}$ ethanol per gm of fermented mass was added and kept at shaking for overnight. It was filtered through Whatman No. 1 filter paper, centrifuged for $15 \mathrm{~min}$ at $10000 \mathrm{rpm}$. The filtrate was further diluted and the absorbance was measured at $510 \mathrm{~nm}$, near the absorbance peak of red pigments. The concentration of Monascus pigment was estimated directly by measurements in the visible spectrum and represented as absorbance units (AU, multiplication of the absorbance with its dilution ratio in the sample). Only extracellular pigments were considered in this study. Only extracellular pigments were considered in this study.

\section{Heat pH and light stability of the pigment}

To assess the heat stability, $10 \mathrm{ml}$ of pigment in glass test tubes were exposed to different temperatures i.e. $40^{\circ} \mathrm{C}, 50^{\circ} \mathrm{C}, 60^{\circ} \mathrm{C}, 70^{\circ} \mathrm{C}, 80^{\circ} \mathrm{C}, 100^{\circ} \mathrm{C}, 121^{\circ} \mathrm{C}$ for 15 $\mathrm{min}$. After cooling to room temperature, absorbance was measured using UV-Vis spectrophotometer and percentage stability was calculated.

Monascus pigment produced during solid state fermentation was adjusted to $\mathrm{pH} \mathrm{2,} \mathrm{4,} \mathrm{6,} \mathrm{8,} \mathrm{10,} 12$ with $1 \mathrm{~N} \mathrm{NaOH}$ or $1 \mathrm{~N} \mathrm{HCl}$. Pigments were analyzed by measuring optical density at $510 \mathrm{~nm}$ after $6 \mathrm{~h}$ of curing. Red pigment produced during solid-state fermentation was exposed to sunlight for $24 \mathrm{hrs}$ and then pigments were analyzed by taking OD at $510 \mathrm{~nm}$.

\section{Evaluation of antimicrobial activity of pigments}

Antibacterial and antifungal activity of the pigment was evaluated against food- borne pathogens such as Bacillus cereus, Staphylococcus aureus, Salmonella, Shigella, Aspergillus flavus, Yeast, Rhizopus, Penicillium and Fusarium spp. Plates of Tryptone Soya Agar and PDA were prepared for bacterial culture and fungal culture respectively and antimicrobial activity of pigments was analyzed using agar well diffusion method by measuring the zone of inhibition. Pigments were concentrated 10 times using rotary evaporator (Heidolf). $100 \mu 1$ of the sample was loaded in the wells and was incubated overnight at $37{ }^{\circ} \mathrm{C}$ for bacterial cultures and at $25^{\circ} \mathrm{C}$ for 5 days for fungal cultures respectively.

\section{Analysis of citrinin using TLC}

Pigments isolated from the submerged and solid state culture were further analysed for presence of citrinin using thin layer chromatography (TLC Silica gel 60, Merck KGA, Germany) in saturated TLC chamber containing toluene: ethyl acetate: formic acid (6:3:1). Approximately $5 \mu \mathrm{l}$ of each sample were spotted on plate. Standard citrinin $5 \mu 1$ was also spotted on TLC plate for comparative analysis. The spotted TLC plate was then air dried, placed vertically in the solvent filled chamber. The plate was developed for approximately 20 
min or until the solvent front reached $1 \mathrm{~cm}$ from the finishing line (Rasheva et al., 2003). TLC plates were observed under UV lamp using shorter and longer wavelength under dark conditions.

\section{Results and discussion}

\section{Pigment production in submerged fermentation}

Monascus purpureus grew rapidly on media such as synthetic medium, PDA and chemical medium while the pigment and biomass production varied on different media. Maximum pigment production was observed on seventh day in synthetic medium $(3.6 \mathrm{AU} / \mathrm{ml})$ followed by PDB (3.4 AU/ml) and Malt extract $(2.8 \mathrm{AU} / \mathrm{ml})$ as shown in Fig 1 a.

Maximum biomass production was observed seventh day in PDB $(0.72 \mathrm{~g} / 100 \mathrm{ml})$, followed by synthetic medium $(0.70 \mathrm{~g} / 100 \mathrm{ml})$ and Malt extract medium $(0.53 \mathrm{~g} / 100 \mathrm{ml})$. Monascus growing in PDB and synthetic media showed maximum pigment yield because the media contains optimum carbon-nitrogen ratio along with starch. Based on the yield, the synthetic medium was further optimized for carbon sources, nitrogen sources and fermentation parameters such as $\mathrm{pH}$ and temperature.

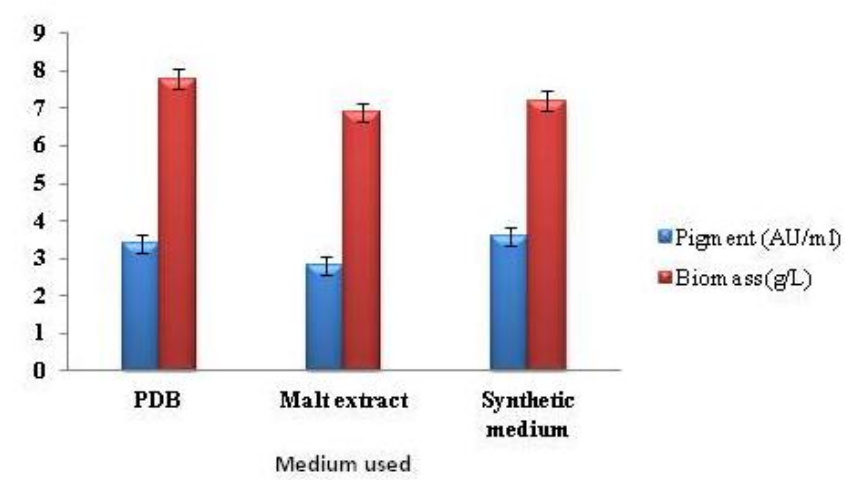

Fig. 1a: Pigment production and biomass yield in submerged fermentation.

\section{Effect of carbon sources on biomass and pigment production}

Red pigment production (4.1 AU/ml) and biomass yield $(6.2 \mathrm{~g} / \mathrm{L})$ was found to increase with glucose as carbon source while maltose resulted more orange and yellow pigments (Figs. 1b and 1c). Previous reports have also indicated that pigment production is more in the presence of glucose in case of Monascus species
(Juzlova et al., 1996). There was an increase in the biomass as well as pigment production with increasing glucose concentration. Some workers reported that a high glucose concentration $(50 \mathrm{~g} / \mathrm{l})$ leads to low growth rates and pigment synthesis (Chen and Johns, 1994).

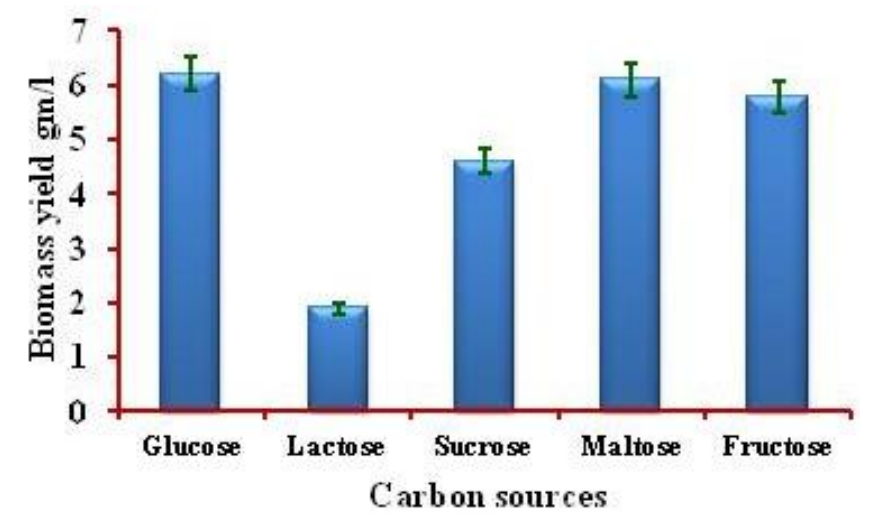

Fig. 1b: Effect of carbon sources on biomass yield.

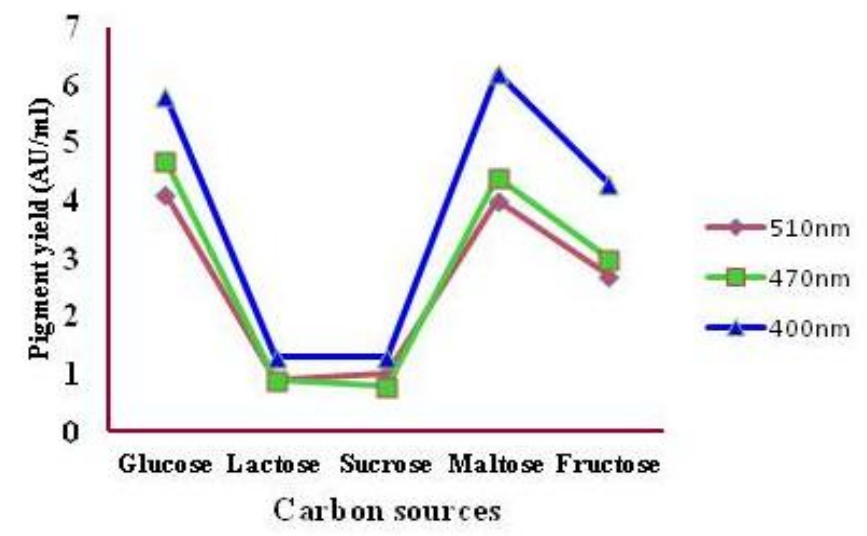

Fig. 1c: Effect of carbon sources on ankaflavin (yellow), rubropunctatin (orange) and rubropuncatmine (red) pigment production.

\section{Effect of nitrogen sources on biomass and pigment production}

Maximum biomass yield was found in yeast extract (7.1 $\mathrm{g} / \mathrm{L}$ ) in the growth medium (Fig. 2a). Ammonium nitrate as a nitrogen source in the growth medium resulted in maximum red $(4.81 \mathrm{AU} / \mathrm{ml}$ ) and orange pigment production shown in Fig $2 \mathrm{~b}$. Other authors have also reported that the best nitrogen source used for good pigment yields is $\mathrm{NH}_{4} \mathrm{Cl}$ and peptone (Juzlova et al., 1996; Chen and Johns, 1993), but yeast extractstimulated biomass production. The nitrogen sources monosodium glutamate and yeast extract favoured the growth of $M$. purpureus strains (Blanc et al., 1995). 


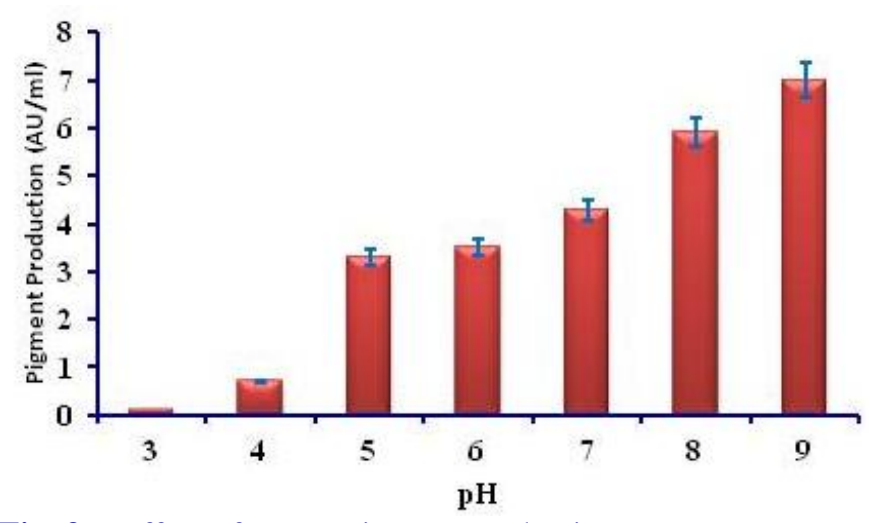

Fig. 3a: Effect of $\mathrm{pH}$ on pigment production.

\section{Effect of pH on biomass and pigment production}

Medium $\mathrm{pH}$ is one of the most critical factors for determining the pigment yield and biomass. Synthetic medium optimized with glucose as a carbon source and ammonium nitrate as nitrogen was used to determine optimum $\mathrm{pH}$ for red pigment production. The initial $\mathrm{pH}$ value of the medium markedly influenced red pigment formation. It was found that $\mathrm{pH}$ in the range of 7.0 to 9.0 favoured red pigment productions as shown in Fig. 3a. An increase in extracellular absorbance for red pigment was found at alkaline pH (Orozco and Kilikian, 2008). Maximum biomass production was noticed at $\mathrm{pH}$ 4.0. Low $\mathrm{pH}(\mathrm{pH}$ 4.0) favoured fungal growth (Chen and Johns, 1993). Also, the change in the final $\mathrm{pH}$ of the medium is shown in Table 2. Table indicates that final $\mathrm{pH}$ of the medium after fermentation determines the red pigment production.

Table 2. Change in media $\mathrm{pH}$ during submerged fermentation.

\begin{tabular}{ll}
\hline Initial $\mathbf{p H}$ & Final $\mathbf{~} \mathbf{H}$ \\
\hline 3 & 3.32 \\
4 & 3.71 \\
5 & 4.07 \\
6 & 4.32 \\
7 & 4.71 \\
8 & 4.80 \\
9 & 5.11 \\
\hline
\end{tabular}

Effect of temperature on biomass and pigment production

Maximum biomass and red pigment $(3.4 \mathrm{AU} / \mathrm{ml})$ was produced at $25^{\circ} \mathrm{C}$ (Fig. 3b). Temperature plays an important role in microbial growth and other metabolic activities. The result obtained above clearly indicates the fungus is mesophilic in nature. It was found that maximum absorbance at $510 \mathrm{~nm}$ (red pigment) was obtained around 25 to $32^{\circ} \mathrm{C}$, while beyond $40^{\circ} \mathrm{C}$; there was a drastic reduction in the amount of red pigment. It was reported that there is shift in absorbance maxima of the pigment extract at different incubation temperatures (Carvalho et al., 2005). Reports also revealed that the optimum cultural conditions for Monascus purpureus pigment production is 3 days of incubation period at $32^{\circ} \mathrm{C}$, and pH 6.0 (Lin et al., 2008).

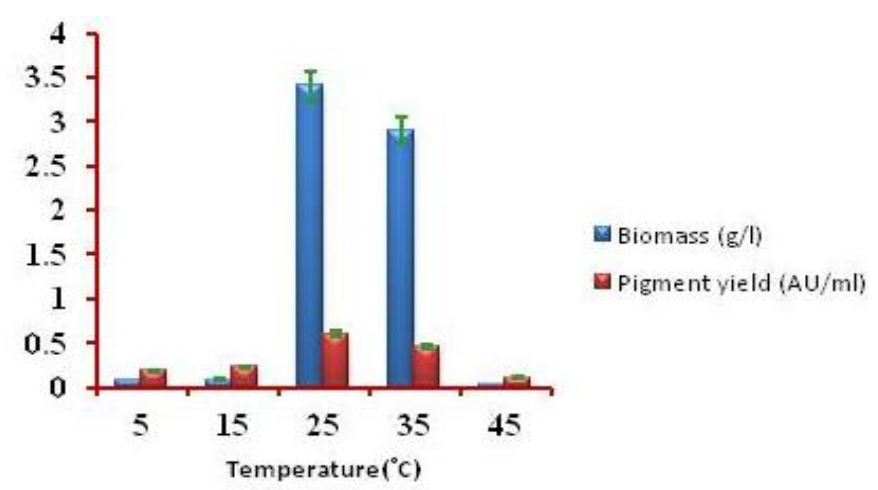

Fig. 3b: Effect of temperature on pigment production.

\section{Pigment production in solid- state fermentation (SSF)}

During solid state fermentation, rice substrate showed highest pigment production (65 AU/gds) followed by wheat (62 AU/gds), jackfruit seed powder (60 AU/gds) and cotton (58 AU/gds) as shown in Fig. 4a. This may be due to chemical composition of rice $(7.2 \%$ protein, $4.0 \mathrm{mg} / \mathrm{kg}$ thiamine, $50.91 \mathrm{mg} / \mathrm{kg}$ niacin, $0.9 \mathrm{mg} / \mathrm{kg}$ riboflavin, $14.9 \mathrm{mg} / \mathrm{kg}$ pantothenic acid, $5.1 \mathrm{mg} / \mathrm{kg}$ Vitamin $B_{6}, 200 \mu \mathrm{g} / \mathrm{kg}$ folate, etc.) which is richer in proteins, vitamins and amino acids. Pigment production can be accomplished with Monascus sp. by fermentation technique using agricultural products other than rice. Corn meal has been reported to be good substrate for the pigment production followed by peanut meal, coconut residue, and soybean meal (Pongrawee and Lumyong, 2011). Others reported that local unpolished rice and Fagopyrum spp were also suitable substrates for Monascus purpureus (Dikshit et al., 2012). Maximum red pigment yield by solid state fermentation was observed when the substrates were supplemented with 5\% glycerol and Oryza sp. with 2\% peptone (Dikshit and Padmavathi, 2013). Other workers concluded that jackfruit seed could be an effective substrate for the production of pigments by Monascus sp. (Babitha et al., 2006). According to Vidyalakshmi et al. (2009) solid state cultivation results in higher pigment yield than cultivation in shake culture and this is caused by the fact that pigments are accumulated in the mycelium under 
submerged cultivation and the pigments are released into grains in solid- state cultivation. The nitrogen source, mono sodium glutamate (MSG) increased $56 \%$ pigment production by $M$. ruber. Others nitrogen sources like yeast extract, ammonium chloride, sodium nitrate, peptone had also been reported for increased pigment production (Vidyalakshmi et al., 2009). The advantage of using cotton as a substrate is that mycelium formation is very less. The pigment released is absorbed in the cotton which can be extracted with the solvent and the cotton can be autoclaved and reused 2-3 times for the pigment synthesis.
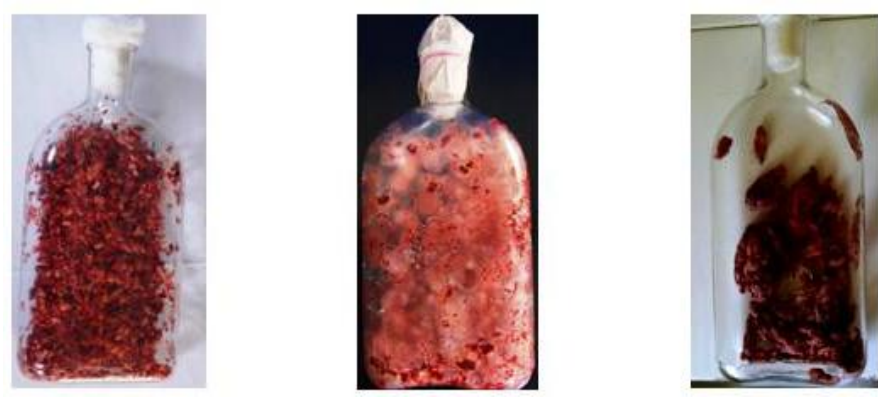

Fig. 4: Solid- state fermentation using rice and wheat and cotton matrix (soaked with potato dextrose medium).

\section{Stability of pigment}

The effect of various physical parameters viz. temperature, $\mathrm{pH}$ and light were studied on the pigment stability. Pigment was found to be stable at temperatures $40^{\circ} \mathrm{C}, 70^{\circ} \mathrm{C}, 90^{\circ} \mathrm{C}$ and $121^{\circ} \mathrm{C}$ after the heat treatment for $15 \mathrm{~min}$. The intensity of red colour increased with heat treatment above $70^{\circ} \mathrm{C}$. Some workers reported that red pigment changes to blackish red at $100^{\circ} \mathrm{C}$ due to breakdown of pigment molecules in solution (Fabre et al., 1993; Lee and Chen, 2000). The pigment was found to be stable at $\mathrm{pH} 4.0$ to 9.0. Exposure of the pigment to acidic or basic environments for $6 \mathrm{hrs}$ didn't result in any loss of red colour. Some authors have reported faster degradation of red pigment above $\mathrm{pH} 8.0$ or below $\mathrm{pH} 4.0$ but $\mathrm{pH}$ stability of Monascus pigment have been achieved by maintaining $\mathrm{pH}$ in the range from 6.0 to 8.0 by adding appropriate buffers and solvents (Fabre et al., 1993; Lee and Chen, 2000). Monascus pigment was found to be sensitive towards light (69.0 AU decreased to $52.0 \mathrm{AU}$ ) after $6 \mathrm{hrs}$ of direct exposure to sunlight. There was a $35 \%$ reduction in the colour intensity after 6 hrs of exposure to direct sunlight due to photodegradation of the pigment. Same observation has been made by other workers. They reported that Monascus pigments are unstable towards light due to rapid degradation of secondary metabolites (Fabre et al., 1993; Lee and Chen, 2000). Jung et al. (2005) studied the degradation patterns and derivatization from red pigment gradually to brown pigment by HPLC analysis. These workers also reported that addition of amino acids to the culture media may increase the half-life of the pigment during exposure to sunlight or UV light. This may be possible probably due to their derivatization or complexation.

\section{Antimicrobial activity of the pigment}

Antimicrobial activity of the pigment was evaluated against various food borne pathogens. The pigment showed activity against $S$. aureus, Shigella spp., $B$. mycoides and B. cereus. Previous studies have shown that citrinin, an antibacterial substance produced by Monascus species has a strong inhibitory effect against gram-positive bacteria ( $\mathrm{Su}$ et al., 2003; Vendruscolo et al., 2014). Our investigation is also in agreement with the results of the $M$. purpureus NTU 601 strain proven to produce citrinin (Ribeiro et al., 1997) which postulated that the antibacterial effect of citrinin on $B$. subtilis was related to the size of the inhibition zone. So, it was observed that Monascus pigment besides colour provides preservation value. Fig. 5 shows activity of the Monascus pigment produced on different agricultural substrate against $S$. aureus. Pigment produced on wheat substrate showed maximum zone of inhibition $(6.0 \pm 0.2$ $\mathrm{mm})$. No zone of inhibition was found in the pigment produced with cotton matrix. The antimicrobial action is attributed to the citrinin biosynthesis.

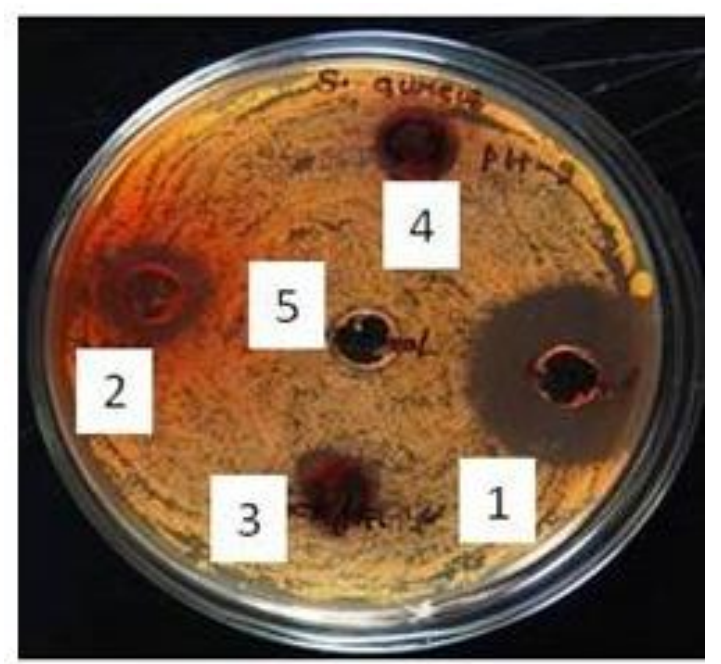

Fig. 5: Antimicrobial activity of Monascus pigment extracted from 1) wheat, 2) rice, 3) jackfruit seed, 4) cotton and 5) control (ethanol) against Staphylococcus aureus. 


\section{TLC analysis of citrinin}

Usually, pigment produced by Monascus is associated with toxin citrinin. The citrinin within the extract needs to be detoxified for use as food colour. The extracted pigment was analyzed using silica gel 60 plate along with the standard citrinin $(0.2 \mathrm{mg} / \mathrm{ml})$. It was developed on toluene: ethyl acetate: formic acid (6:3:1) till it reached $1 \mathrm{~cm}$ from the top. The plate was then air dried and visualized under longer wavelength of UV at 365 $\mathrm{nm}$ as lemon yellow fluorescence. Bright fluorescence for citrinin was found in case of wheat as compared to standard citrinin. Biosynthesis of citrinin was also persistent when rice and jackfruit seed powder was used as a substrate. But no citrinin was detected in cotton substrate using TLC as shown in Fig. 6.

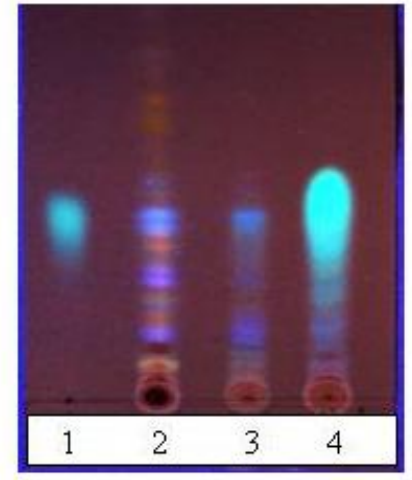

(a)

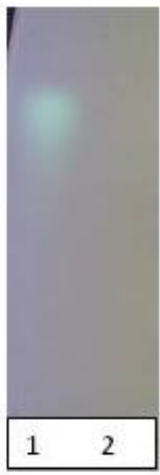

(b)
Fig. 6a: TLC of ethanolic extract of pigment: 1) citrinin standard, 2) rice, 3) jackfruit seed powder, 4) wheat. Fig. 6b: TLC of ethanolic extract of pigment: 1) citrinin standard, 2) cotton wick.

The TLC result is in agreement with the antimicrobial activity of the secondary metabolite citrinin. Low protein content of the cotton matrix drenched with potato dextrose medium is attributed to lower citrinin biosynthesis. Xiong et al. (2014) also demonstrated that optimal selection of agricultural products with low level of protein content would provide a novel strategy to inhibit citrinin in submerged culture fermentation of Monascus anka and at a low initial $\mathrm{pH}$ for the production of Monascus pigments. It was also found that the nature of nitrogen source was directly related to the final $\mathrm{pH}$ of the medium, which regulated the composition of Monascus pigments and the citrinin biosynthesis. Thus, an ideal nitrogen source can be selected to manage the final $\mathrm{pH}$ and thus the citrinin biosynthesis. Citrinin- free orange pigments were also produced at extremely low initial $\mathrm{pH}$ in the medium with nitrogen source as $(\mathrm{NH} 4)_{2} \mathrm{SO}_{4}$ or MSG. Wang et al. (2016) studied citrinin inhibition at extremely low $\mathrm{pH}$ which was further confirmed by extractive fermentation of intracellular pigments in the nonionic surfactant Triton X-100 micelle aqueous solution.

\section{Conclusion}

The synthetic medium containing glucose, ammonium nitrate at $27^{\circ} \mathrm{C}$ and $\mathrm{pH} 9.0$ showed 1.5 fold increases in the pigment yield. Solid state fermentation was found more effective than submerged fermentation. The rice substrate showed maximum pigment production (65.0 AU/gds) followed by wheat (62.0 AU/gds) followed by jackfruit seed powder (60.0 AU/gds) and cotton substrate $(58.0$ AU/gds). High concentrations of Monascus pigment without citrinin (as shown in TLC) have been achieved in the study using solid- state fermentation with cotton as a matrix may be due to low protein concentration of the substrate. Cotton matrix drenched with potato dextrose broth was first time used as a solid substrate for the pigment production which can also be reused. This may be a simple strategy for the inhibition of citrinin biosynthesis during the Monascus pigment production.

\section{Conflict of interest statement}

Authors declare that they have no conflict of interest.

\section{References}

Babitha, S., Soccol, C. R., Pandey, A., 2006. Jackfruit seed - A novel substrate for the production of Monascus pigments through solid-state fermentation. Food Technol. Biotechnol. 44(4), 465471.

Babitha, S., Soccol, C.R., Pandey, A., 2007. Solid-state fermentation for the production of Monascus pigments from jackfruit seed. Bioresour. Technol. 98, 1554-1560.

Blanc, P. J., Loret, M. O., Goma, G., 1995. Production of citrinin by various species of Monascus. Biotech. Lett. 17(3), 291-294.

Carvalho, J.C., Oishi, B.O., Pandey, A., Soccol, C. R., 2005. Biopigments from Monascus: Strains selection, citrinin production and color stability. Braz. Arch. Biol. Technol. 48(6), 885-894.

Carvalho, J.C., Oishi, B.O., Woiciechowski, A.L., Pandey, A., Babitha, S., Soccol, C.R., 2007. Effect of substrates on the production of Monascus 
biopigments by solid-state fermentation and pigment extraction using different solvents. Indian $\mathrm{J}$. Biotech. 6, 194-199.

Chang, Y., Huang, J., Lee, C., Shih, I., Tzeng, Y., 2002. Use of response surface methodology to optimize culture medium for production of lovastatin by Monascus ruber. Enz. Microb. Technol. 30, 889894.

Chen, M., Johns, M. R., 1994. Effect of carbon source on ethanol and pigment production by Monascus purpureus. Enz. Microb. Technol. 16, 584-590.

Chen Ming-Ho, Johns, M. R., 1993. Effect of $\mathrm{pH}$ and nitrogen source on pigment production by Monascus purpureus. Appl. Microbiol. Biotechnol. 40(1), 132138.

Dikshit, P., Maneerat, S., Kittikun, A. H., 2012. Mannoprotein from spent yeast obtained from Thai traditional liquor distillation: Extraction and characterization. J. Food Process. Eng. 35, 166-177.

Dikshit, R., Padmavathi, R., 2013. Exploring Monascus sanguineus as a potential natural source for pigment production. Int. Res. J. Biol. Sci. 2(5), 59-67.

Fabre, C. E., Goma, G., Blanc, P. J., 1993. Production and food applications of the red pigments of Monascus ruber. J. Food Sci. 58, 1099-1110.

Gunasekaran, S., Poorniammal, R., 2008. Optimization of fermentation conditions for red pigment production from Penicillium sp. under submerged cultivation. Afr. J. Biotechnol. 7(12), 1894-1898.

Gunjan, M., Sanjay, K. S., 2011. Purification and characterization of a new red pigment from Monascus purpureus in submerged fermentation process. Biochem. 46, 188- 192.

Hajjaj, H., Blanc, P.J., Groussac, E., Goma, G., Uribelarrea, J.L., Loubiere, P., 2000a. Improvement of red pigment/citrinin production ratio as a function of environmental conditions by Monascus ruber. Biotechnol. Bioeng. 64(4), 497-501.

Hajjaj, H., Klaébé, A., Goma, G., Blanc, P. J., Barbier, E., François, J., 2003. Medium-chain fatty acids affect citrinin production in the filamentous fungus Monascus ruber. Appl. Environ. Microbiol. 66(3), 1120-1125.

Hamano, P. S., Kilikian, B. V., 2006. Production of red pigments by Monascus ruber in culture media containing corn steep liquor. Braz. J. Chem. Eng. 23(4), 443-449.

Hesseltine, C., 1965. A millennium of food, fungi and fermentation. Mycologia. 57, 149-197.

Hsu, W. H., Lee, B. H., Pan, T. M., 2010. Protection of Monascus - fermented dioscorea against DMBA- induced oral injury in hamster by anti-inflammatory and antioxidative potentials. J.Agri. Food. Chem. 58, 6715-6720.

Jung H, Kim C, Shin CS. (2005). Enhanced Photostability of Monascus pigments derived with various amino acids via fermentation. J Agric Food Chem. 53(18):7108-7114.

Juzlova P, Martinkova L, Kren V. (1996). Secondary metabolites of the fungus Monascus: A review. J Indust Microbiol. 16:163-170.

Kono I, Himeno K. (1999). Antimicrobial activity of Monascus pilosus IFO 4520 against contaminant of Koji. Biosci Biotechnol Biochem. 63(8):14941496.

Lee YK, Chen DC. (2000). Applications of Monascus pigments as food colorant. Disp.in: http://www.allok.com/literature

Lin YL, Wang TH, Lee MH, Su NW. (2008). Biologically Active Components and Neutraceuticals in the Monascus Fermented Rice, a review. Appl Microbiol Biotechnol. 77:965-973.

Orozco SFB, Kilikian BV. (2008). Effect of $\mathrm{pH}$ on citrinin and red pigments production by Monascus purpureus CCT3802. World J Microbiol Biotechnol. 24: 263-268.

Pisareva E, Savov V, Kujumdzieva A. (2005). Pigments and citrinin biosynthesis by fungi belonging to genus Monascus. Z Naturforsch. 60:116-120.

Pongrawee N, Lumyong S. (2011). Improving SolidState Fermentation of Monascus purpureus on Agricultural Products for Pigment Production. Food Bioprocess Microbiol Biotechnol. 24:263-268.

Rasheva T, Nedeva T, Hallet JN, Kujumdzieva A. (2003). Characterization of a non-pigment producing Monascus purpureus mutant strain. Antonie van Leeuwenhoek, J Microbiol Serol. 83:333-340.

Ribeiro SMR., Chagas GM., Campello AP., Kluppel MLW. (1997). Mechanism of citrinin-induced dysfunction of mitochondria. Effect on the homeostasis of the reactive oxygen species. Cell Biochem Funct. 15:203-209.

Su YC, Wang JJ, Lin TT and Pan TM. (2003). Production of the secondary metabolites çaminobutyric acid and monacolin K by Monascus. J. Ind. Microbiol. Biotechnol. 30:40-46.

Vendruscolo, F., Tosin, I., Giachini, A. J., Schmidell, W. and Ninow, J. L. (2014). Antimicrobial Activity of Monascus Pigments Produced in Submerged Fermentation. J Food Proc Preserv. 38: 1860-1865.

Vidyalakshmi R, Paranthaman R, Murugesh S, 
Singaravadivel K. (2009). Stimulation of Monascus pigments by intervention of different nitrogen sources. Global J Biotechnol Biochem. 4:25-28.

Wang, B., Zhang, X., Wu, Z. (2016). Biosynthesis of Monascus pigments by resting cell submerged culture in nonionic surfactant micelle aqueous solution. Appl. Microbiol. Biotechnol. 100, 7083-7089.

Wong HC, Lin YC, Koehler PE. (1981). Regulation of growth and pigmentation of Monascus purpureus by carbon and nitrogen concentration. Mycologia.
73:649-654.

Xiong, X., Zhang, X., Wu, Z. (2014). Optimal Selection of Agricultural Products to Inhibit Citrinin Production during Submerged Culture of Monascus anka. Biotechnol Bioproc Eng. 19:1005-1013.

Zhou B, Pu YW, Zhu MJ, Liang SZ. (2008). Effects of nitrogen sources on Monascus yellow pigment production by Monascus mutant. Modern Food Sci Technol. 2:123-127.

\section{How to cite this article:}

Neera, Dhananjay, K., Venkata Ramana, K., Sharma, R. K., 2017. Optimization of Monascus pigment production and its antibacterial activity. Int. J. Curr. Res. Biosci. Plant Biol. 4(3), 71-80.

doi: https://doi.org/10.20546/ijcrbp.2017.403.008 